\title{
REUSE OF SUBSTRATE IN THE PROTECTED CULTIVATION OF MUSKMELON $^{1}$
}

\author{
PABLO FORLAN VARGAS ${ }^{2}$, ATALITA FRANCIS CARDOSO ${ }^{3}$, HAMILTON CÉSAR DE OLIVIERA CHARLO ${ }^{4}$, \\ RENATA CASTOLDI ${ }^{5}$, LEILA TREVISAN BRAZ ${ }^{3}$
}

\begin{abstract}
Melon is a vegetable of great socioeconomic importance, and its cultivation is carried out under different production systems. The protected cultivation of melon can be carried out in coconut shell fiber, which is a substrate widely used in olericulture, but little information is available regarding its continuous use in more than one cultivation cycle. Therefore, this study aimed to evaluate the performance of muskmelon hybrids as a function of the reuse of coconut shell fiber with fertigation in a protected environment. The experiment was carried out in a greenhouse from March to July 2008 and designed in randomized blocks in a $2 \times 3$ factorial arrangement, with four replications. The factors consisted of two hybrids ('Bonus 2' and 'Fantasy') and three types of substrate (S1: new coconut shell fiber; S2: coconut shell fiber reused once in sweet pepper cultivation; and S3: coconut shell fiber reused twice, i.e., first in sweet pepper cultivation and then in melon cultivation). Transverse and longitudinal fruit diameter, fruit shape index, transverse and longitudinal locule diameter, locule shape index, peduncle insertion diameter, mesocarp thickness, firmness, skin netting, fresh mass, soluble solids, titratable acidity, $\mathrm{pH}$, and yield were evaluated after harvest. Reusing twice the coconut shell fiber as a substrate did not affect the agronomic and physicochemical characteristics of the hybrids Bonus 2 and Fantasy.
\end{abstract}

Keywords: Cucumis melo. Substrate. Yield. Fertigation.

\section{REUSO DE SUBSTRATO NO CULTIVO DE MELOEIRO RETICULATUS SOB CULTIVO PROTEGIDO}

RESUMO - O meloeiro é uma hortaliça de grande importância socioeconômica, sendo seu cultivo realizado em diferentes sistemas produção. Em ambiente protegido o cultivo do meloeiro pode ser realizado em em fibra da casca de coco, que é um substrato amplamente utilizado na olericultura, contudo, poucas informações existem quanto ao uso continuo de um mesmo substrato em mais de um ciclo de cultivo. Assim, objetiva-se avaliar o desempenho de híbridos de melão rendilhado em função da reutilização da fibra da casca de coco com fertirrigação em ambiente protegido. $\mathrm{O}$ experimento foi conduzido em casa de vegetação de março a julho de 2008. O experimento foi delineado em blocos casualizados, esquema fatorial $2 x 3$, com quatro repetições. Os fatores foram dois híbridos, 'Bônus no 2' e 'Fantasy' e três tipos de utilização de substrato (S1 = fibra da casca de coco nova; S2 = fibra da casca de coco reutilizada uma vez na cultura do pimentão; e, S3 = fibra da casca de coco reutilizada por duas vezes, la na cultura do pimentão e 2a na cultura do melão). Após a colheita foram avaliados: diâmetro transversal e longitudinal do fruto, índice de formato de fruto, diâmetro transversal e longitudinal do lóculo, índice de formato do lóculo, diâmetro da inserção do pedúnculo, espessura do mesocarpo, firmeza, rendilhamento da casca, massa fresca, sólidos solúveis, acidez titulável, $\mathrm{pH}$ e produtividade. Com base nos resultados, concluiu-se o reuso de fibra da casca de coco como substrato por duas vezes não alterou as características agronômicas e físico-químicas dos híbridos Bônus n.2 e Fantasy.

Palavras-chave: Cucumis melo. Substrato. Produtividade. Fertirrigação.

\footnotetext{
${ }^{*}$ Corresponding author

${ }^{1}$ Received for publication in 09/24/2020; accepted in 04/23/2021.

Paper extracted from the Master of Science dissertation of the second author.

${ }^{2}$ Department of Agronomy, Universidade Estadual Paulista, Registro, SP, Brazil; pablo.vargas@unesp.br - ORCID: 0000-0002-5718-6403.

${ }^{3}$ Departmen of Agricultural Production Sciences, Universidade Estadual Paulista, Jaboticabal, SP, Brazil; atalitacardoso@yahoo.com.br ORCID: 0000-0002-1063-4264, leila.braz@unesp.br-ORCID: 0000-0003-1420-0364.

${ }^{4}$ Department of Agronomy, Instituto Federal de Educação, Ciência e Tecnologia do Triângulo Mineiro, Uberaba, MG, Brazil; hamiltoncharlo@iftm.edu.br - ORCID: 0000-0003-0663-2167.

${ }^{5}$ Institute of Agricultural Sciences, Universidade Federal de Uberlândia, Monte Carmelo, MG, Brazil; rcastoldi@ufu.br - ORCID: 00000001-9406-0917.
} 


\section{INTRODUCTION}

Melon (Cucumis melo L.) is a widely consumed and highly popular vegetable species worldwide, with a production of $27,349,214 \mathrm{t}$ in 2018, with China being the largest producer $(12,727,263 \mathrm{t})$, that is, $46.53 \%$ of global production (FAO, 2020). Brazil ranks 12th among the largest producers, with a production volume of 581,478 t (FAO, 2020).

Brazil exported 251,641 t of melons in 2019 (ABRAFRUTA, 2020), becoming one of the largest exporters in the world, with the European and North American markets the largest international centers for the consumption of Brazilian melons. Moreover, the opening of the Chinese market starting in 2020 for this vegetable has led to an expectation of substantial increases in exports in the coming years.

Favorable climate conditions and the evolution of cultivation techniques have allowed increasing yield and improve the quality of Brazilian production. Also, Brazil is favored in the commercial aspect, as domestic production occurs in the offseason of other countries, mainly those of the northern hemisphere, facilitating the sale of the Brazilian product.

Although most of the production consists of yellow melons, there is a growing interest in the production of noble melons, popularly known as muskmelons (VENDRUSCOLO et al., 2018). These melons have gained prominence because they are aromatic, have a high soluble solids content, light green or salmon pulp, and net skin (SANTOS et al., 2015), characteristics that promote the interest of consumers.

Cultivation in a protected environment has important advantages over cultivation in the open field, as there is the possibility of partial or total control of climate factors, such as radiation, temperature, and relative humidity. Thus, protected cultivation provides a better environment for the development of plants, which can express their productive potential.

In addition to the protected cultivation, the fertigation system in the substrate is widely used in vegetable fruits, as it promotes advantages relative to soil cultivation, such as precocious harvest, increased yield, and better quality of the harvested fruit (VARGAS et al., 2008a,b; CHARLO et al., 2011).

Coconut shell fiber stands out among the possible substrates to be used, as it provides a suitable environment for root development, with high water retention and porosity, although its production, concentrated in the North region of Brazil, makes the final product more expensive (ZORZETO; FERNANDES JÚNIOR; DECHEN, 2016) when it is used in other regions. Furthermore, it is ecologically correct and has a good quality and high availability (BERRUTI; SCARIOT, 2012).

Coconut shell fiber as a substrate for melon production has been studied in different areas of the agricultural sciences, such as salt concentration of the hydroponic solution (DIAS et al., 2011; MORAIS et al., 2018; CARVALHO et al., 2018), nitrogen to potassium ratio in the nutrient solution (NASCIMENTO; NASCIMENTO; CECÍLIO FILHO, 2020), concentration of macronutrients in the nutrient solution (COSME et al., 2017; GRATIERI et al., 2013), and analysis of plant growth (DIAS et al., 2015).

The reuse of this substrate in successive cultivations may become an interesting alternative of management to be used by producers due to its high cost. Thus, this study aimed to evaluate the performance of muskmelon hybrids grown on reused coconut shell fiber substrate.

\section{MATERIAL AND METHODS}

The study was carried out from March 2008 to July 2008 in a greenhouse located in the Sector of Olericulture and Aromatic-Medicinal Plants of the School of Agricultural and Veterinary Sciences (FCAV-UNESP), campus of Jaboticabal, SP, Brazil. The local altitude is $614 \mathrm{~m}$, with a latitude of $21^{\circ} 14^{\prime}$ $05^{\prime \prime} \mathrm{S}$ and longitude of $48^{\circ} 17^{\prime} 09^{\prime \prime} \mathrm{W}$.

The greenhouse consisted of a metal structure with an arched ceiling of $3 \mathrm{~m}$ in height, $30 \mathrm{~m}$ in length, and $6 \mathrm{~m}$ in width, covered with a 150-micron transparent polyethylene film treated against ultraviolet rays, and sides protected with 50\% shading black propylene screens.

The experiment was randomized in blocks in a $2 \times 3$ factorial arrangement. The first factor consisted of two muskmelon hybrids ('Bonus 2' and 'Fantasy') and three types of substrates ( $\mathrm{S} 1$ : new coconut shell fiber; S2: coconut shell fiber reused once in sweet pepper cultivation; and S3: coconut shell fiber reused twice, i.e., first in sweet pepper cultivation and then in melon cultivation), with four replications. Each plot consisted of six pots, in which the first and last plants were considered as a border, remaining four central plants for evaluation.

Sowing was carried out in 128-cell expanded polystyrene trays, with transplanting carried out at 15 days after sowing, when the plants had the first definitive leaf fully expanded.

Melon cultivation was carried out in $13-\mathrm{dm}^{3}$ polyethylene pots, which were filled with coconut shell fiber. The content of pots from treatments in which the substrates were reused was not disturbed, that is, the plants were cut close to the substrate level.

The pots were arranged in double rows with spacings of $0.8 \mathrm{~m}$ between single rows, $0.5 \mathrm{~m}$ 
between plants in the row, and 1.10 between double rows. Drip irrigation with the nutrient solution recommended for the crop was used according to Castellane and Araújo (1994) for hydroponic cultivation. The recommendation of macronutrients and micronutrients $\left(\mathrm{g} \mathrm{L}^{-1}\right)$ consisted of $178(\mathrm{~N}), 93$ (P), $265(\mathrm{~K}), 153(\mathrm{Ca}), 21.6(\mathrm{Mg}), 28.9(\mathrm{~S}), 0.30(\mathrm{~B})$, $2.35(\mathrm{Fe}), 0.3(\mathrm{Mn}), 0.23(\mathrm{Zn}), 0.03(\mathrm{Cu})$, and 0.04 (Mo).

Fertigation was controlled by a timer, starting at $8 \mathrm{am}$ and ending at $6 \mathrm{pm}$. The system was activated automatically according to the scheduled operating time. The schedule and water depth applied were defined according to the crop age and minimum drainage of the pots. The rates of application by irrigation were $84 \mathrm{~mL} \mathrm{~h}^{-1}$ from 1 to 15 days after transplanting (DAT), $98 \mathrm{~mL} \mathrm{~h}^{-1}$ from 15 to $30 \mathrm{DAT}, 126 \mathrm{~mL} \mathrm{~h}^{-1}$ from 30 to $40 \mathrm{DAT}$, $140 \mathrm{~mL} \mathrm{~h}^{-1}$ from 40 to $50 \mathrm{DAT}, 182 \mathrm{~mL} \mathrm{~h}^{-1}$ from 50 to $60 \mathrm{DAT}$, and $210 \mathrm{~mL} \mathrm{~h}^{-1}$ from 60 to $93 \mathrm{DAT}$ (MELO et al., 2012).

Plant staking was performed with plastic strips attached to wires located close to the soil and $2 \mathrm{~m}$ high. Pruning was carried out when plants reached $2 \mathrm{~m}$ high. Shoots up to the 8 th node and after fruit fixation were removed and plant tying was carried out whenever necessary. Pollination was carried out manually and thinning was performed whenever necessary after the fruits were established to leave two fruits per plant.

Disease control was carried out as required using pesticides registered for the crop. Gummy stem blight (Didymella bryoniae), downy mildew (Pseudoperonospora cubensis), and whitefly (Bemisia tabaci) needed to be controlled using the active ingredients iprodione, chlorothalonil, and sulfoxaflor (sulfoxamine), respectively.

Harvest was carried out when the fruit abscission region showed a crack in its entire perimeter. The following characteristics were evaluated: transverse and longitudinal fruit diameter, obtained using a digital caliper, with values expressed in millimeters; fruit shape index, obtained by the ratio between the averages of the transverse and longitudinal fruit diameters; transverse and longitudinal locule diameter, obtained by a digital caliper, with values expressed in millimeters; locule shape index, obtained by the ratio between the averages of the transverse and longitudinal locule diameters; peduncle insertion diameter, obtained using a digital caliper; mesocarp thickness, obtained using a digital caliper; pulp firmness, obtained by a digital penetrometer, with values expressed in Newton $(\mathrm{N})$; skin netting, obtained by adopting a score scale in which score 1 was assigned to fruits with a weak netting, score 2 was assigned to fruits with a medium netting, and score 3 was assigned to fruits with an intense netting; fresh fruit mass, measured using a digital scale with a variation of \pm 5 g; soluble solids, obtained on a manual refractometer, with values expressed in Brix corrected to $20{ }^{\circ} \mathrm{C} ; \mathrm{pH}$, determined in the juice extract using a digital $\mathrm{pH}$ meter; titratable acidity, obtained from a $10-\mathrm{mL}$ aliquot of juice to which 40 $\mathrm{mL}$ of distilled water and three drops of $1 \%$ alcoholic phenolphthalein indicator were added, followed by titration with $0.1 \mathrm{~N} \mathrm{NaOH}$ solution until the turning point; and yield, measured by the production obtained in the plot and converted into $\mathrm{tha}^{-1}$

The statistical treatment was performed using the analysis of variance, with the means of the evaluated characteristics compared by the Tukey test at a 5\% probability, using the statistical program AGROESTAT (BARBOSA; MALDONADO JUNIOR, 2015).

\section{RESULTS AND DISCUSSION}

The factors were presented and discussed individually due to the absence of significant interaction between them for the evaluated characteristics (Tables 1 and 2).

The transverse fruit diameter showed no significant differences for both hybrid and substrate factors, with a mean of $120.76 \mathrm{~mm}$. On the contrary, the longitudinal fruit diameter presented a difference only for the hybrid factor, in which the diameter of the hybrid Fantasy was $40 \mathrm{~mm}$ higher than that of the hybrid Bonus 2. The fruit shape index was higher in the hybrid Fantasy (1.01) than the hybrid Bonus 2, with no differences between substrates (Table 1).

The size of melon fruits is an important characteristic, as that marketing is carried out using boxes with fixed dimensions, with a varying number of fruits per carton according to their size. Therefore, larger fruits allowed a lower number of fruits per box, leading to savings to the agricultural entrepreneur due to less use of boxes. In addition, the cylindrical shape (fruit shape index $\approx 1$ ) of fruits obtained in the present study also brings benefits in their better fitting in the packing. Thus, substrate reuse did not interfere with fruit size (transverse and longitudinal diameter) and shape.

Fruits of the hybrid Fantasy tended to be more oblong than fruits of the hybrid Bonus 2, which have a characteristic of more elliptical fruits. This difference in the fruit shape index occurred due to the differences found in the longitudinal fruit diameter. 
Table 1. Mean values for the transverse fruit diameter (TFD), longitudinal fruit diameter (LFD), fruit shape index (FSI), transverse locule diameter (TLD), longitudinal locule diameter (LLD), locule shape index (LSI), peduncle insertion diameter (PID), and mesocarp thickness (MT) of two muskmelon hybrids as a function of substrate reuse.

\begin{tabular}{|c|c|c|c|c|c|c|c|c|}
\hline Treatment & $\begin{array}{l}\text { TFD } \\
(\mathrm{mm})\end{array}$ & $\begin{array}{l}\text { LFD } \\
(\mathrm{mm})\end{array}$ & FSI & $\begin{array}{l}\text { TLD } \\
(\mathrm{mm})\end{array}$ & $\begin{array}{l}\text { LLD } \\
(\mathrm{mm})\end{array}$ & LSI & $\begin{array}{l}\text { PID } \\
(\mathrm{mm})\end{array}$ & $\begin{array}{l}\text { MT } \\
(\mathrm{mm})\end{array}$ \\
\hline \multicolumn{9}{|l|}{ Hybrid (H) } \\
\hline Bonus 2 & $120.71 a^{1}$ & $119.36 b$ & $0.98 \mathrm{~b}$ & $56.90 \mathrm{a}$ & $79.18 \mathrm{a}$ & $1.39 \mathrm{a}$ & $7.41 \mathrm{a}$ & $33.47 \mathrm{a}$ \\
\hline Fantasy & $120.82 \mathrm{a}$ & $123.36 \mathrm{a}$ & $1.01 \mathrm{a}$ & $59.11 \mathrm{a}$ & $80.50 \mathrm{a}$ & $1.36 \mathrm{a}$ & $7.29 \mathrm{a}$ & $34.71 \mathrm{a}$ \\
\hline F-test & $0.01^{\mathrm{ns}}$ & $9.55^{* *}$ & $13.76^{*}$ & $3.31^{\mathrm{ns}}$ & $0.49^{\mathrm{ns}}$ & $0.78^{\mathrm{ns}}$ & $0.19^{\mathrm{ns}}$ & $1.20^{\mathrm{ns}}$ \\
\hline LSD & 3.26 & 2.86 & 0.01 & 2.59 & 4.04 & 0.72 & 0.56 & 2.40 \\
\hline \multicolumn{9}{|l|}{ Substrate (S) } \\
\hline S1 & $120.90 \mathrm{a}$ & $121.10 \mathrm{a}$ & $0.99 \mathrm{a}$ & $58.38 \mathrm{a}$ & $81.18 \mathrm{a}$ & $1.39 \mathrm{a}$ & $7.10 \mathrm{a}$ & $33.99 \mathrm{a}$ \\
\hline S2 & $119.93 a$ & $121.51 \mathrm{a}$ & $1.00 \mathrm{a}$ & $57.54 \mathrm{a}$ & $80.00 \mathrm{a}$ & $1.39 \mathrm{a}$ & $7.72 \mathrm{a}$ & $33.83 \mathrm{a}$ \\
\hline S3 & $121.46 \mathrm{a}$ & $121.71 \mathrm{a}$ & $0.99 \mathrm{a}$ & $58.38 \mathrm{a}$ & $78.31 \mathrm{a}$ & $1.35 \mathrm{a}$ & $7.24 \mathrm{a}$ & $34.46 \mathrm{a}$ \\
\hline F-test & $0.07^{\mathrm{ns}}$ & $0.07^{\mathrm{ns}}$ & $0.78^{\mathrm{ns}}$ & $0.16^{\mathrm{ns}}$ & $0.76^{\mathrm{ns}}$ & $0.62^{\mathrm{ns}}$ & $1.97^{\mathrm{ns}}$ & $0.12^{\mathrm{ns}}$ \\
\hline LSD & 4.86 & 4.27 & 0.02 & 3.86 & 6.03 & 0.10 & 0.85 & 3.58 \\
\hline Interaction $\mathrm{H} \times \mathrm{S}$ & $1.21^{\mathrm{ns}}$ & $1.54^{\mathrm{ns}}$ & $0.82^{\text {ns }}$ & $0.81^{\mathrm{ns}}$ & $0.53^{\mathrm{ns}}$ & $2.21^{\mathrm{ns}}$ & $1.97^{\mathrm{ns}}$ & $1.29^{\mathrm{ns}}$ \\
\hline CV $(\%)$ & 3.11 & 2.71 & 6.19 & 5.14 & 5.83 & 6.04 & 8.92 & 8.11 \\
\hline
\end{tabular}

${ }^{1}$ Means followed by the same letter in the column do not differ from each other by the Tukey's test at a 5\% probability. *Significant at a $5 \%$ probability level. ${ }^{* *}$ Significant at a $1 \%$ probability level. ${ }^{\text {ns }}$ Not significant.

The transverse and longitudinal locule diameter showed no differences between factors, with overall means of 57.00 and $79.83 \mathrm{~mm}$, respectively (Table 1). Vargas et al. (2008a) found similar values.

Moreover, no differences were observed between treatments for the locule shape index. Lower values of the internal cavity are related to qualitative aspects of fruits, as smaller cavities provide higher resistance to the release of placenta and fruit seeds, thus avoiding possible fermentation (SIQUEIRA et al., 2009).

Peduncle insertion diameter showed no differences between treatments, with a mean of 7.35 $\mathrm{mm}$. Vargas et al. (2008a) found similar values in cultivation carried out using coconut shell fiber substrate. The authors evaluated this characteristic in two cultivation systems (soil and substrate), evidencing the superiority of plants grown on the substrate.

Mesocarp thickness presented no differences between treatments, with an overall mean of 34.08 $\mathrm{mm}$, which is adequate for melons of the reticulatus group (VARGAS et al., 2008b). A higher pulp thickness is highly desirable, as it is the edible part of the fruit, increasing its mass. It is a characteristic related to transport and marketing, and the larger the mesocarp, the better the transport resistance and the longer the post-harvest durability of the fruit (SANTOS et al., 2011).

The hybrid Bonus 2 was firmer than the hybrid Fantasy (Table 2). On the other hand, substrate reuse did not interfere with this characteristic, that is, fruit firmness did not change in three successive cultivations on the same substrate. Therefore, substrate reuse did not interfere with the constitution of the cell wall of fruits. Firmness is essential in post-harvest handling, as firmer fruits are more resistant to mechanical injuries that occur during transport and marketing (CHAVES et al., 2014), allowing the fruits to be marketed far from the consumer center or even being exported.

Netting was not influenced by the factors hybrid and substrate. All the means presented values close to three, which is the maximum skin netting of fruits (Table 2). Vargas et al. (2008b) found higher netting values in fruits grown under a substrate compared to fruits grown in the soil. The external melon appearance is a quality attribute and melons with a high intensity of skin netting are desired commercially, as they become attractive to the consumer.

Fruit fresh mass was not influenced by the studied factors, with a mean value of $0.99 \mathrm{~kg}_{\text {fruit }}{ }^{-1}$. This fruit fresh mass is ideal for the domestic and international market of the reticulatus group, which has preferences for melons weighing close to $1 \mathrm{~kg}$ (SANTOS et al., 2015). Vargas et al. (2008b) worked with five muskmelon cultivars ('Maxim', 'Louis', 'Fantasy', 'Shinju 200' and 'Bonus 2') under two cultivation systems (soil and coconut shell fiber substrate) and found fruit mass values ranging from 0.88 ('Bonus 2') to $1.22 \mathrm{~kg}$ ('Fantasy'). In the present study, the hybrid 'Bonus 2' showed higher values than those found in the mentioned study, demonstrating that the cultivation on reused substrates provides fruits with the mass required by the consumer market. The possible decomposition of the coconut shell fibers that make up the substrate did not affect the development of melon plants and the productive capacity of the evaluated cultivars. 
Table 2. Mean values of firmness (F), skin netting (SN), fresh mass (FM), soluble solids (SS), titratable acidity (TA), acidity $(\mathrm{pH})$, and yield $(\mathrm{Y})$ of two muskmelon hybrids as a function of substrate reuse.

\begin{tabular}{|c|c|c|c|c|c|c|c|}
\hline Treatment & $\begin{array}{c}\mathrm{F} \\
(\mathrm{N})\end{array}$ & $\begin{array}{c}\mathrm{SN} \\
\text { (Score) }\end{array}$ & $\begin{array}{l}\mathrm{FM} \\
(\mathrm{kg})\end{array}$ & $\begin{array}{c}\text { SS } \\
{ }^{\circ} \text { Brix }\end{array}$ & TA & $\mathrm{pH}$ & $\begin{array}{c}\mathrm{Y} \\
\left(\mathrm{t} \mathrm{ha}^{-1}\right)\end{array}$ \\
\hline \multicolumn{8}{|l|}{ Hybrid (H) } \\
\hline Bonus 2 & $13.77 \mathrm{a}^{1}$ & $2.90 \mathrm{a}$ & $0.97 \mathrm{a}$ & $12.84 \mathrm{a}$ & $0.11 \mathrm{a}$ & $6.14 \mathrm{a}$ & $38.45 \mathrm{a}$ \\
\hline Fantasy & $12.22 \mathrm{~b}$ & $2.96 \mathrm{a}$ & $1.02 \mathrm{a}$ & $12.49 \mathrm{a}$ & $0.11 \mathrm{a}$ & $6.08 \mathrm{a}$ & $40.70 \mathrm{a}$ \\
\hline F-test & $5.67 *$ & $0.39^{\mathrm{ns}}$ & $2.08^{\mathrm{ns}}$ & $1.94^{\mathrm{ns}}$ & $0.44^{\mathrm{ns}}$ & $0.81^{\mathrm{ns}}$ & $2.06^{\mathrm{ns}}$ \\
\hline LSD & 1.47 & 0.21 & 0.83 & 0.53 & 0.13 & 0.14 & 33.33 \\
\hline \multicolumn{8}{|l|}{ Substrate (S) } \\
\hline S1 & $13.03 \mathrm{a}$ & $2.90 \mathrm{a}$ & $0.98 \mathrm{a}$ & $12.62 \mathrm{a}$ & $0.11 \mathrm{a}$ & $6.02 \mathrm{a}$ & $39.20 \mathrm{a}$ \\
\hline S2 & $12.87 \mathrm{a}$ & $3.00 \mathrm{a}$ & $1.00 \mathrm{a}$ & $12.51 \mathrm{a}$ & $0.11 \mathrm{a}$ & $6.07 \mathrm{a}$ & $40.25 \mathrm{a}$ \\
\hline S3 & $13.03 \mathrm{a}$ & $2.91 \mathrm{a}$ & $0.99 \mathrm{a}$ & $12.86 \mathrm{a}$ & $0.11 \mathrm{a}$ & $6.21 \mathrm{a}$ & $39.28 \mathrm{a}$ \\
\hline F-test & $0.01^{\mathrm{ns}}$ & $0.57^{\mathrm{ns}}$ & $0.19^{\mathrm{ns}}$ & $0.67^{\mathrm{ns}}$ & $0.37^{\mathrm{ns}}$ & $2.92^{\text {ns }}$ & $0.19^{\mathrm{ns}}$ \\
\hline LSD & 2.20 & 0.31 & 0.12 & 0.79 & 0.01 & 0.22 & 49.81 \\
\hline Interaction $\mathrm{H} \times \mathrm{S}$ & $0.72^{\mathrm{ns}}$ & $0.92^{\mathrm{ns}}$ & $2.39^{\mathrm{ns}}$ & $3.13^{\mathrm{ns}}$ & $2.92^{\mathrm{ns}}$ & $2.36^{\mathrm{ns}}$ & $2.37^{\mathrm{ns}}$ \\
\hline $\mathrm{CV}(\%)$ & 13.09 & 8.34 & 9.72 & 4.87 & 13.38 & 2.79 & 9.70 \\
\hline
\end{tabular}

${ }^{1}$ Means followed by the same letter in the column do not differ from each other by the Tukey's test at a $5 \%$ probability. ${ }^{*}$ Significant at a $5 \%$ probability level. ${ }^{\text {ns }}$ Not significant.

The characteristics that make up the fruit flavor (soluble solids, titratable acidity, and $\mathrm{pH}$ ) presented no differences between treatments, with means of $12.7,0.11$, and 6.10 , respectively. Fruits of the reticulatus group with soluble solids above 9\% are considered suitable for export (APEX-BRASIL, 2014). On the other hand, acidity has little impact due to its low concentration $(0.11 \%)$, not being very representative in flavor (MEDEIROS et al., 2012).

Substrate reuse showed no influence on some organoleptic characteristics studied here and, therefore, the changes that occurred in the substrate with successive cultivation cycles were not able to interfere with the chemical characteristics of melon fruits. The reuse of coconut shell fiber did not induce phytotoxicity, with no negative effects on the quality of cherry tomato fruits in Italy, allowing the reuse of this substrate at least three times (CAPODILUPO; STIPIC; VENEZIA, 2015), which corroborates with the present study.

Yield showed no significant difference between factors. The mean yield reached $39.57 \mathrm{t}$ $\mathrm{ha}^{-1}$, which is higher than the mean yield of $30 \mathrm{tha}^{-1}$ obtained by traditional Brazilian producers. The results found in our study are lower than those found by Vargas et al. (2008a), who cultivated muskmelon in fiber from the coconut shell and obtained a mean yield of $50.20 \mathrm{t} \mathrm{ha}^{-1}$. However, the study was carried out in the summer, with higher air temperatures and day length, favoring photosynthesis and photoassimilate production, unlike the present study, which was carried out in the autumn/winter.

Substrate reuse did not influence yield. Therefore, the substrate can be reused for up to three cultivations without prejudice to the yield and quality of the melon fruit. In addition, substrate reuse is a way to reduce production costs, as it is not necessary to purchase a new substrate for each cultivation cycle, as well as labor costs. MartínezGutiérrez et al. (2015) observed that the almond shell substrate can be used for up to 695 days without prejudice to melon and tomato. Therefore, further studies on the reuse of coconut fiber are required to ascertain its maximum time of use without causing damage to the agronomic characteristics and physicochemical quality of fruits.

\section{CONCLUSION}

Reusing twice the coconut shell fiber as a substrate did not affect the yield of the hybrids Bonus 2 and Fantasy.

\section{REFERENCES}

ABRAFRUTA - Associação Brasileira dos Produtores Exportadores de Frutas e Derivados. Estatística de exportações de frutas em 2019. Disponível em: <https:// abrafrutas.org/2020/01/28/8825/>. Acesso em: 08 jul. 2020 .

APEX-BRASIL. Agência Brasileira de Promoção de Exportações e Investimentos. Perfil exportador de melões brasileiros. Brasília: Apex-Brasil, 2014. 48 p.

BARBOSA, J. C; MALDONADO, JUNIOR, W. Experimentação Agronômica \& Agroestat sistema para análises estatísticas de ensaios 
agronômicos. Jaboticabal, SP: FUNEP, 2015. 396 p.

BERRUTI, A.; SCARIOT, V. Fibra de coco: um substrato semelhante apeat para cultivo de plantas acidófilas. ActaHorticulturae, 952: 629-635, 2012.

CAPODILUPO, M.; STIPIC, M.; VENEZIA, A. Soilless cultivation of cherry tomato with gutter subirrigation and reused substrate.Advances in Horticultural Science, 29: 121-124, 2015.

CARVALHO, I. D. E. et al. Effect of Saline Concentrations in Melon under Different Substrates in Hydroponic System. Journal of Experimental Agriculture International, 22: 1-12, 2018.

CAStellane, P. D.; ARAúJo, J. A. C. Cultivo sem solo: Hidroponia. Jaboticabal, SP: FUNEP, 1994. $43 \mathrm{p}$

CHAVES, S. W. P. et al. Conservação de melão Cantaloupe cultivado em diferentes doses de N e K. Horticultura Brasileira, 32: 468-474, 2014.

CHARLO, H. C. O. et al. Híbridos experimentais de melão rendilhado cultivados em solo e substrato. Revista Brasileira de Fruticultura, 33: 144-156, 2011.

COSME, C. R. et al. Yield and quality of 'gália' melon grown in coconut fiber under different concentrations of macronutrients in the nutrient solution. Idesia, 35: 119-128, 2017.

DIAS, N. S. et al. Growth of melon plants in coconut saline nutrient solution. Irriga, 20: 1-12, 2015.

DIAS, N. S. O. et al. Concentração salina e fases de exposição à salinidade do meloeiro cultivado em substrato de fibra de coco. RevistaBrasileira de Fruticultura, 33:915-921, 2011.

FAO - Food and Agriculture Organization of the United Nations. Melons. Disponível em: $<$ http:// www.fao.org/faostat/en/\#data/QC>. Acesso em: 10 jul. 2020.

GRATIERI, L. A. et al. Nitrogen and potassium concentrations in the nutrients solution for melon plants growing in coconut fiber without drainage.The Scientific World Journal, 2013: 1-10, 2013.

MARTÍNEZ-GUTIÉRREZ, A. B. et al. Effect of particle size and reused organic substrates on tomato crop production. Journal of Plant Nutrition, 38, 1877-1884, 2015.
MEDEIROS, J. F. et al. Efeito da lâmina de irrigação na conservação pós-colheita de melão Pele de Sapo. Horticultura Brasileira, 30: 514-519, 2012.

MELO, D. M. et al. Produção e qualidade de melão rendilhado sob diferentes substratos em cultivo protegido. Revista Caatinga, 25: 58-66, 2012.

MORAIS, P. L. D. et al. Effects of nutrient solution salinity on the physiological performance of melon cultivated in coconut fiber. Revista Caatinga, 31: 713-718, 2018.

NASCIMENTO, C. S; NASCIMENTO, C. S.; CECÍLIO FILHO, A. B. N:K ratio for phenological growth stages of net melon cultivated in NFT hydroponic system. Revista Caatinga, 33: 108-115, 2020

SANTOS, A. F. et al. Qualidade de melão rendilhado sob diferentes doses nutricionais. Revista Verde, 6: 134-145, 2011

SANTOS, F. G. B. et al. Produção e qualidade de melão Cantaloupe em cultivo protegido temporariamente com agrotêxtil em Mossoró, Rio Grande do Norte. Revista Ceres, 62: 93-100, 2015.

SIQUEIRA, W. C. et al. Qualidade de frutos de melão amarelo cultivado em casa de vegetação sob diferentes lâminas de irrigação. Ciência \&Agrotecnologia, 33: 1041-1046, 2009.

VARGAS, P. F. et al. Desempenho de cultivares de melão rendilhado em função do sistema de cultivo. Horticultura Brasileira, 26: 197-201, 2008a.

VARGAS, P. F. et al. Qualidade de melão rendilhado (Cucumis melo L.) em função do sistema de cultivo. Ciência \&Agrotecnologia, 32: 137-142, $2008 b$

VENDRUSCOLO, E. P. et al. A. Suplementação nutricional aumenta qualidade de mudas de melão rendilhado tratadas ou não com tiamina em pré semeadura. Scientia Agraria, 19: 164-171, 2018

ZORZETO, T. Q.; FERNANDES JÚNIOR, F; DECHEN, S. C. F..Granulated coconut fiber and rice husk substrates for the production of 'Oso Grande' strawberry. Bragantia, 75: 222-229, 2016. 